\title{
Method and System of Pre-Sowing Microwave Treatment of Agricultural Crop Seeds
}

\author{
A.V. Kovalev, O.B. Spiridonov, I.E. Lysenko, O.A. Ezhova \\ Southern Federal University, Rostov-on-Don, Russia.
}

(ORCID: 0000-0003-0545-7416) A.V. Kovalev

(ORCID: 0000-0002-6006-0449) O.B. Spiridonov

(ORCID: 0000-0002-7505-1983) I.E. Lysenko

(ORCID: 0000-0002-4277-5723) O.A. Ezhova

\begin{abstract}
In this work, a system of treatment of agricultural crop seeds has been developed. The system contain two blocks: neural network photoseparation block and microwave seed treatment block. The productivity of the seed treatment system is from 2,400 to $4,000 \mathrm{~kg} /$ hour, depending on the content of impurities of the raw material and the mode of microwave seed treatment. The mode of microwave seed treatment should provide maximum disinfection, stimulation of germination and intensity of germination. A model of microwave treatment using two waveguide-slit antennas located on opposite sides and shifted relative to each other in order to create a more uniform distribution in the volume has been developed.
\end{abstract}

Keywords: Agriculture, method, system, microwave treatment, simulation, seed.

\section{INTRODUCTION}

Safety ensuring of food raw materials and food products is the most important priority direction of the policy in the field of healthy nutrition of the population. The developed pre-seed treatment system is designed to disinfect seeds and stimulate the germinating ability of seeds using microwave energy and corona discharge instead of chemical pre-seed treatment. The unit can work independently or as part of a bigger system, in which there are photoseparation system and finishing incrustation of disease-treated seed with biologically active preparations to protect the seed from reinfection with soil phytopathogens.

\section{COMPARATIVE ANALYSIS OF SEED TREATMENT TECHNOLOGIES}

Microwave technology of stimulation and disinfection of agricultural crop seeds allows you to increase production efficiency significantly. This technology is in the lower price range and takes less time. The seed treatment in the microwave unit allows to avoid the disinfection of seeds using pesticides. The use of a microwave device provides significant savings, as well as a very favorable effect on the health of service personnel and the environment [1]-[10].

Another advantage of the new technology is that the seeds that have been processed in the microwave unit, significantly increases laboratory and field germination. And This is observed for almost all of the cultivated crops. Typical cases are when non-standard seed germination increases so much that it allows you to transfer them to the category of conditioned. Microwave field suppresses phytopathogens of seeds and insects, which eliminates the need for the preseeding germination. Microwave technology of presowing seed treatment is stimulation of agricultural seeds with the microwave field created by special devices. There are 3 levels of stimulation: energy, functional, and informational [1]-[10].

The stimulation effects on seeds causes changes in the content of proteins, amminic nitrogen, enzyme activity and activates metabolic processes in seeds. This processes is associated with their bioenergetics, germination, growth strength and in the future with vegetation and yield properties of the seeds. Treated seeds increase field germination rate by $15-20 \%$ and crop yield by $10-30 \%$. As the experience of leading scientific institutions and agricultural enterprises of the country has shown microwave treatment significantly increases the frost tolerance and drought resistance of field crops. In conditions of severe frosts and severe droughts of the last decade crops died on huge areas. And where seeds treated with microwave technology were used, crops unalterably developed without deviations from the norm and gave quite good yields [1]-[10].

Traditional thermal disinfection is too energy-intensive and does not provide $100 \%$ disinfection from viruses and bacteria. Similar equipment for grain disinfection uses infrared heating, ultraviolet radiation, which does not provide uniform heating and complete disinfection. There is a method of seed disinfection by blowing an ozone-air mixture through the product. But this method allows only the surface layer of the seed to be disinfected, leaving alive the eggs of seed pests inside the seed itself. Chemical treatment of seed with stable pesticides is also used, which leads to environmental 
contamination and does not allow the treated seeds to be used for food purposes. All of the above methods differ from the developed method by high economic costs [1]-[10].

There are similar equipment for disinfection of seed using microwave energy and not using pesticides. This equipment allows to disinfect only the eggs of seed pests and the grain surface from pathogens by only $30 \%$. Complete disinfection is possible only when the grain treatment temperature increases to $80{ }^{\circ} \mathrm{C}$, which sharply reduces the seed germination. The developed method does not use pesticides. This method of seed disinfection uses a combined effect of microwave energy and finely dispersed anolyte. Anolyte is activated water obtained by electrolysis. The water has an antiseptic effect or ozonated water. The technology of anolyte humidification allows to disinfect the grain surface and saturate spores and viruses with water. As a result, the absorption capacity of viruses and spores sharply increases so they are strongly heated by microwave energy. The endosperm (starch) absorbs water only at temperatures above $53{ }^{\circ} \mathrm{C}$. So during seed treatment the endosperm absorbs less microwave energy than spores and viruses and, as a result, heats up $10^{\circ} \mathrm{C}$ less than pathogens [1]-[10].

\section{DESCRIPTION OF THE SEED TREATMENT SYSTEM}

The seed treatment system consists of two modules (blocks):

- neural network photo separation unit;

- microwave seed treatment unit.

Figure 1 shows the design of the microwave seed treatment unit. The productivity of the seed treatment system is from 2400 to $4000 \mathrm{~kg} /$ hour. The productivity depends on the contamination of the raw material and the mode of microwave seed treatment, which provides maximum disinfection, stimulation of germination and intensity of germination. The photoseparation unit sorts seeds by appearance, dividing the seed into two streams in two containers. In one container there are good seeds, and in the other container there are weeds and damaged seeds. The separation capacity is $3000 \mathrm{~kg} /$ hour.

The flow rate on the vibrating conveyor is adjusted automatically by changing the angle of inclination of the conveyor from 0 to $20^{\circ}$. One degree of tilt changes the flow rate by $3 \%$. Changing the frequency from 40 to 200 vibrations per minute changes the flow rate twice. The flow rate is controlled by an indirect method at the time of filling the tank from a single level sensor to the other.

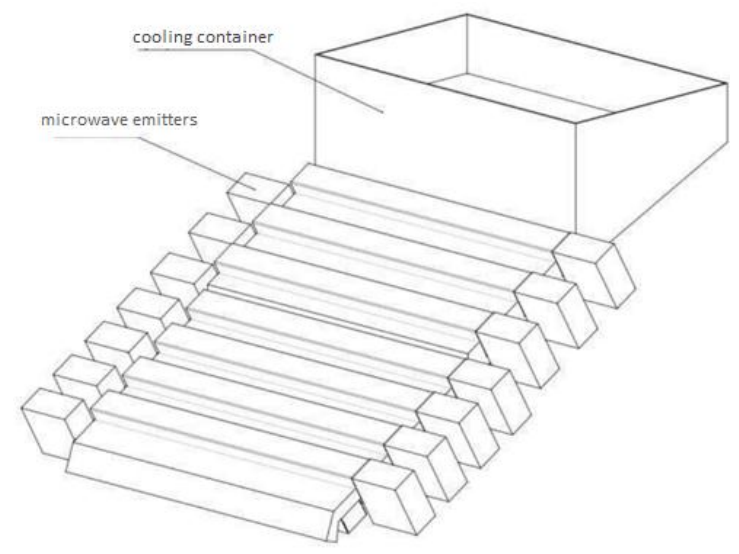

Figure 1. Unit microwave processing of seeds

Additionally, the seeds are treated with corona discharge. This allows you to increase the level of seed disinfection without increasing the temperature of heating the grain with microwave energy. Microwave heating of seeds should not exceed $53^{\circ} \mathrm{C}$, which is not enough for disinfection, since the starch contained in the endosperm does not dissolve in water and does not change its properties. At a temperature of $55^{\circ} \mathrm{C}$ starch reacts with the remains of water molecules, hydrolyzes to form a paste that dries and clogs the respiratory spores of the seed. This increases the level of seed disinfection at a low temperature. This seed treatment contributes to a highly effective stimulation of germination and intensive germination of seeds, which gives an increase in yield by $15-$ $20 \%$. In the unit there is preheating of seed with carbon infrared heaters set above the vibrating conveyor. Carbon IR heaters with a wave length of 1-3. $5 \mathrm{~mm}$ provide volumetric heating of the seed. The vibrating conveyor distributes the seed evenly in one layer, because of a special design of the conveyor bottom which continuously turns the seeds. This design ensures uniform heating of each seed without overheating the surface. The seed is heated to $36-38^{\circ} \mathrm{C}$, moistened with 1-2\% analyte and cooled down for 4-5 minutes. At this temperature seed starch absorbs water and remains radiotransparent. In such favorable temperature and humidity conditions spores and vegetating pathogens greedily absorb water, which dramatically increases the absorption properties of microwave energy.

After cooling, the seeds enter in the microwave chamber where during the exposure time of 20-120 seconds (selected experimentally for maximum stimulation) the seeds are heated to $48-53^{\circ} \mathrm{C}$. This temperature is safe for the seeds while spores and vegetating pathogens are heated higher by $10-12{ }^{\circ} \mathrm{C}$ which is fatal for most of them. The seeds at the output of the vibrating conveyor are moistened with an analyte or ozonated water. Temperature of analyte is $36^{\circ} \mathrm{C}$. During the separation process, the seeds are cleaned from organic impurities (particles of stems, leaves, awns, ear rods), weed impurities (foreign seeds of cultivated and wild plants), 
International Journal of Engineering Research and Technology. ISSN 0974-3154, Volume 13, Number 11 (2020), pp. $3964-3969$

(C) International Research Publication House. https://dx.doi.org/10.37624/IJERT/13.11.2020.3964-3969

harmful impurities (sclerotia, ergot, mustard seeds, chaff, grains affected by Fusarium), and crushed, rotten, dried seeds.

\section{MODELING OF SEED TREATMENT WITH MICROWAVE RADIATION}

The seed treatment equipment is a container with two waveguide-slit antennas which are located on opposite sides and shifted relative to each other in order to create more uniform distribution in the volume. The developed model is shown in Figure 2.

Figures 3-6 show the distribution of the electric field and the specific absorbed power in a vertical plane oriented under the slits of the upper waveguide.

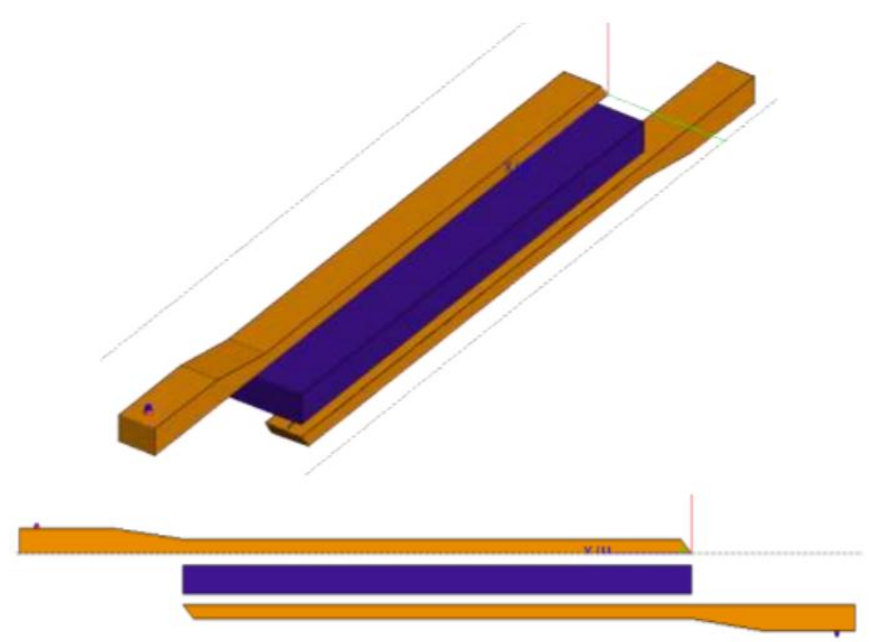

Figure 2. Model of seed treatment with microwave radiation
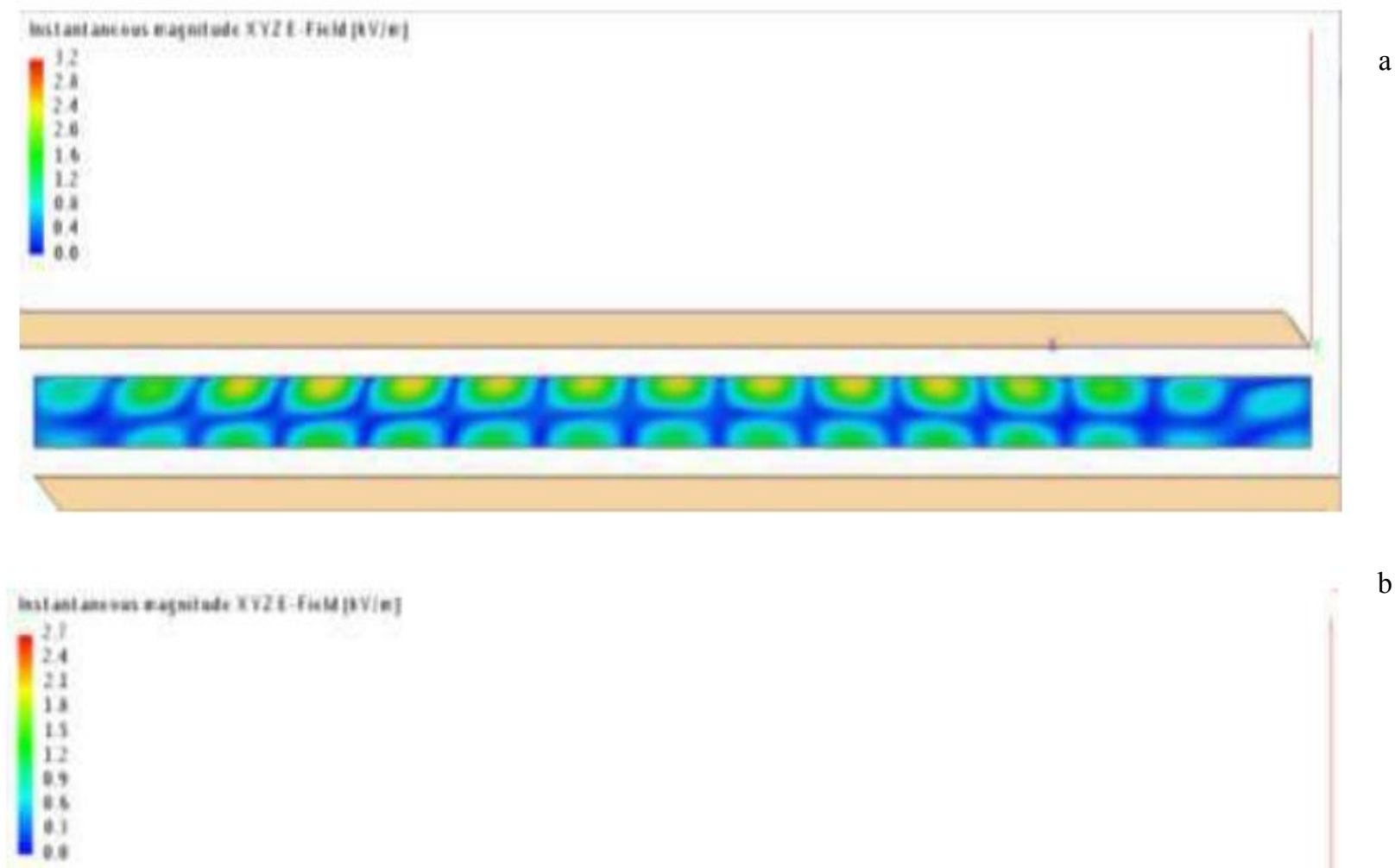

Figure 3. Distribution of the electric field under the upper waveguide in the vertical plane 
International Journal of Engineering Research and Technology. ISSN 0974-3154, Volume 13, Number 11 (2020), pp. $3964-3969$

(C) International Research Publication House. https://dx.doi.org/10.37624/IJERT/13.11.2020.3964-3969
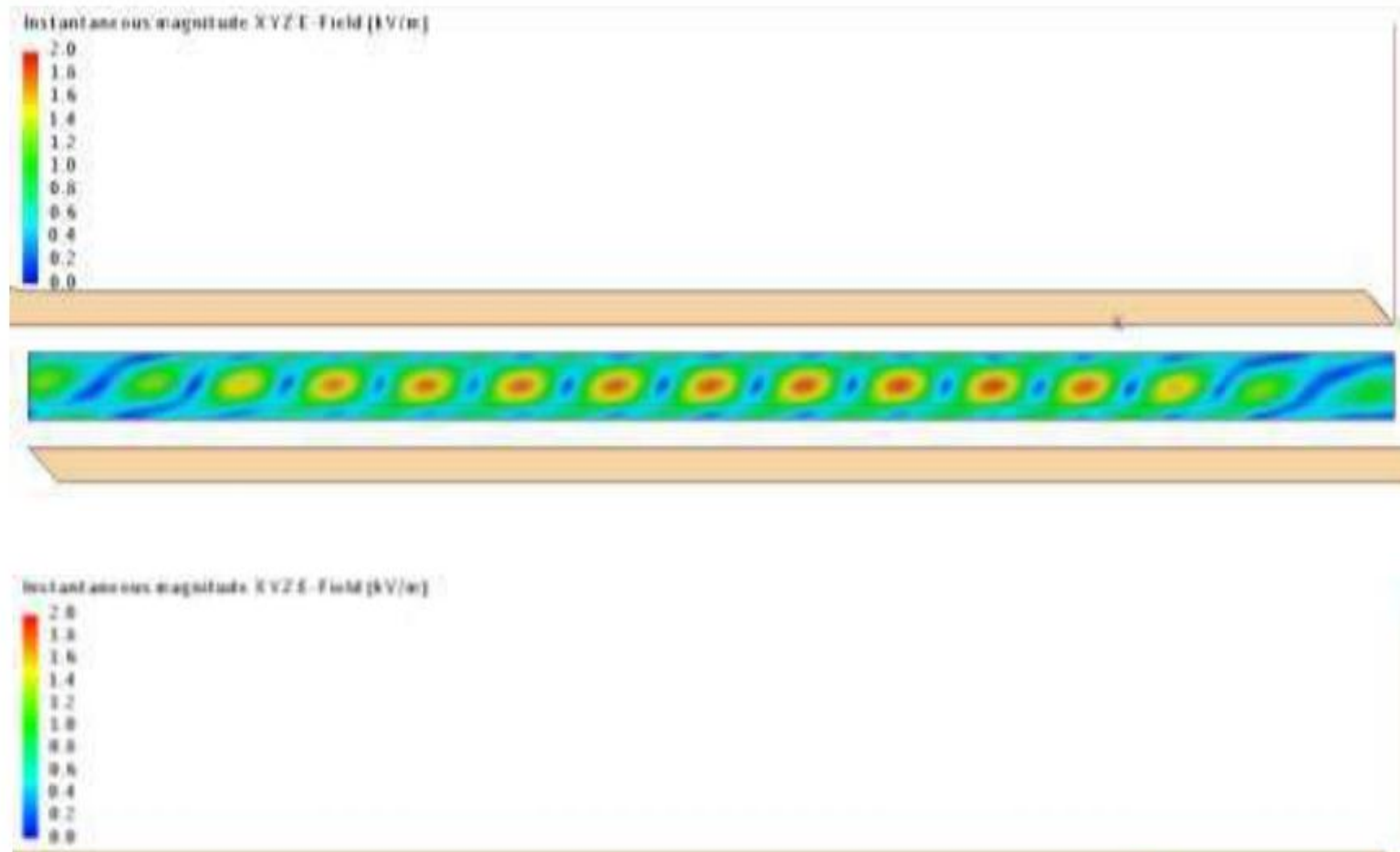

Figure 4. Distribution of the electric field in the middle of the seed layer in the vertical plane
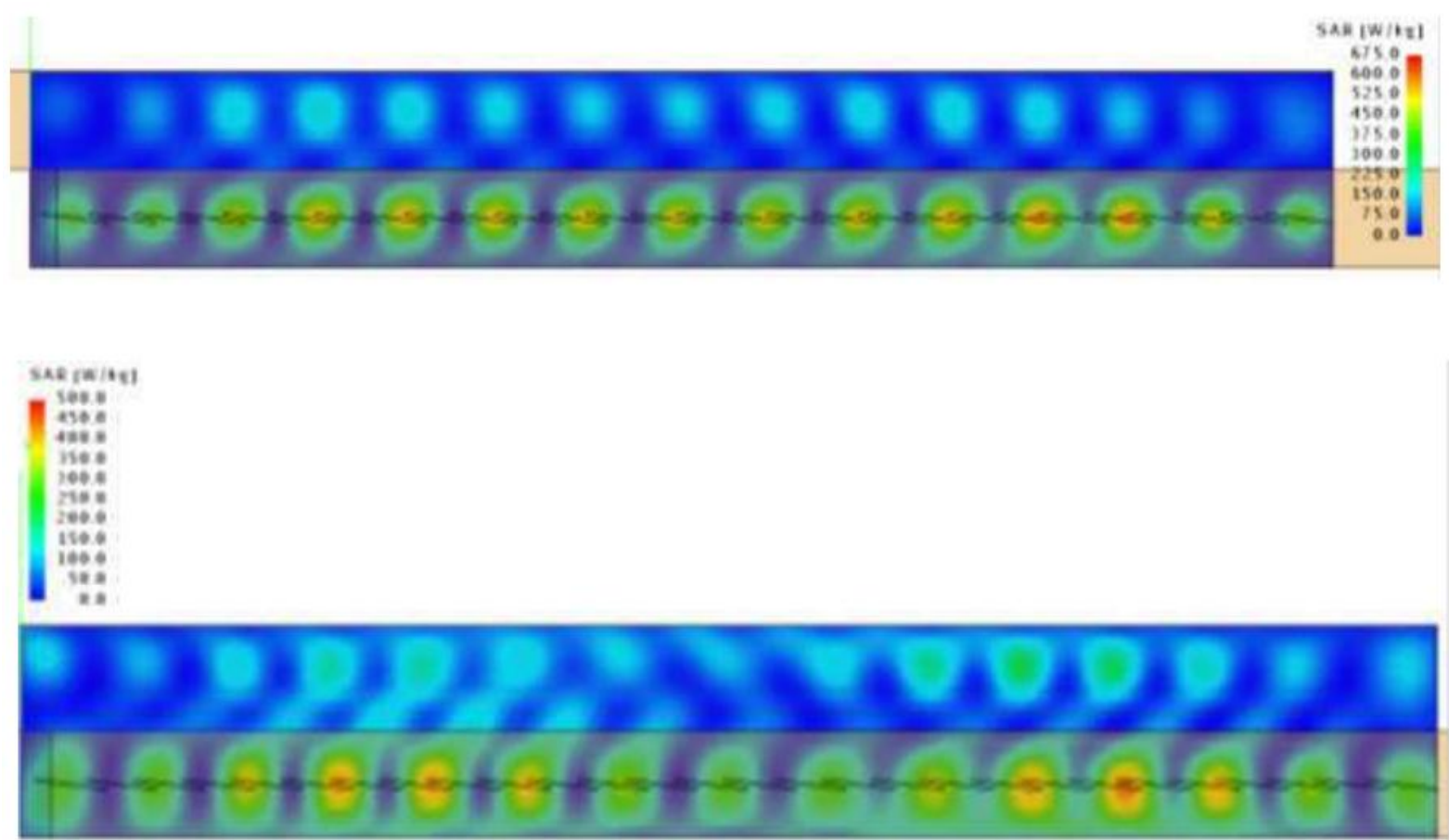

Figure 5. Distribution of specific absorbed power under the upper waveguide in the horizontal plane 
International Journal of Engineering Research and Technology. ISSN 0974-3154, Volume 13, Number 11 (2020), pp. $3964-3969$

(C) International Research Publication House. https://dx.doi.org/10.37624/IJERT/13.11.2020.3964-3969

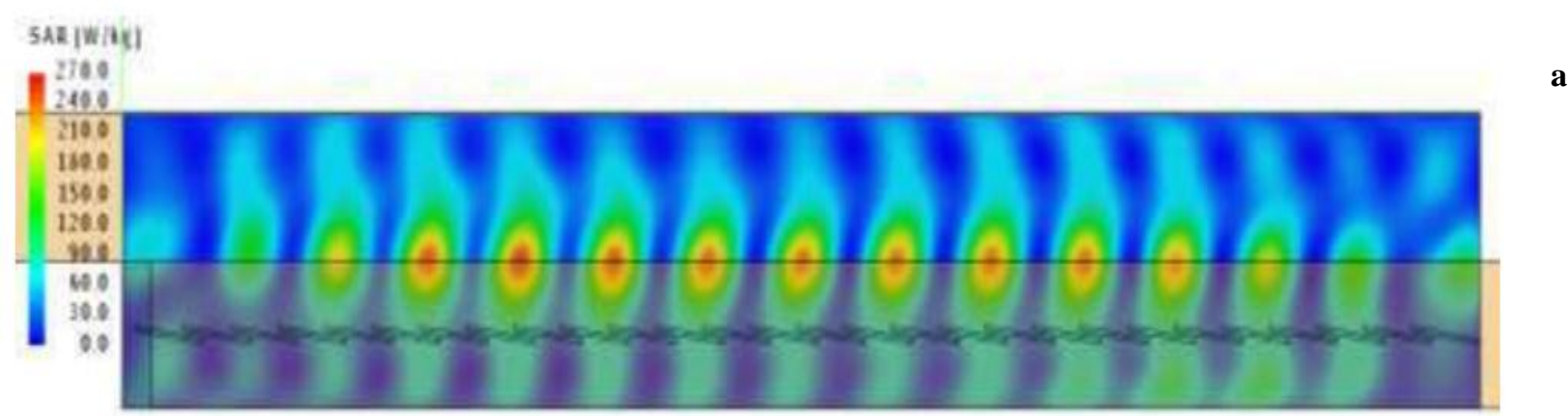

a
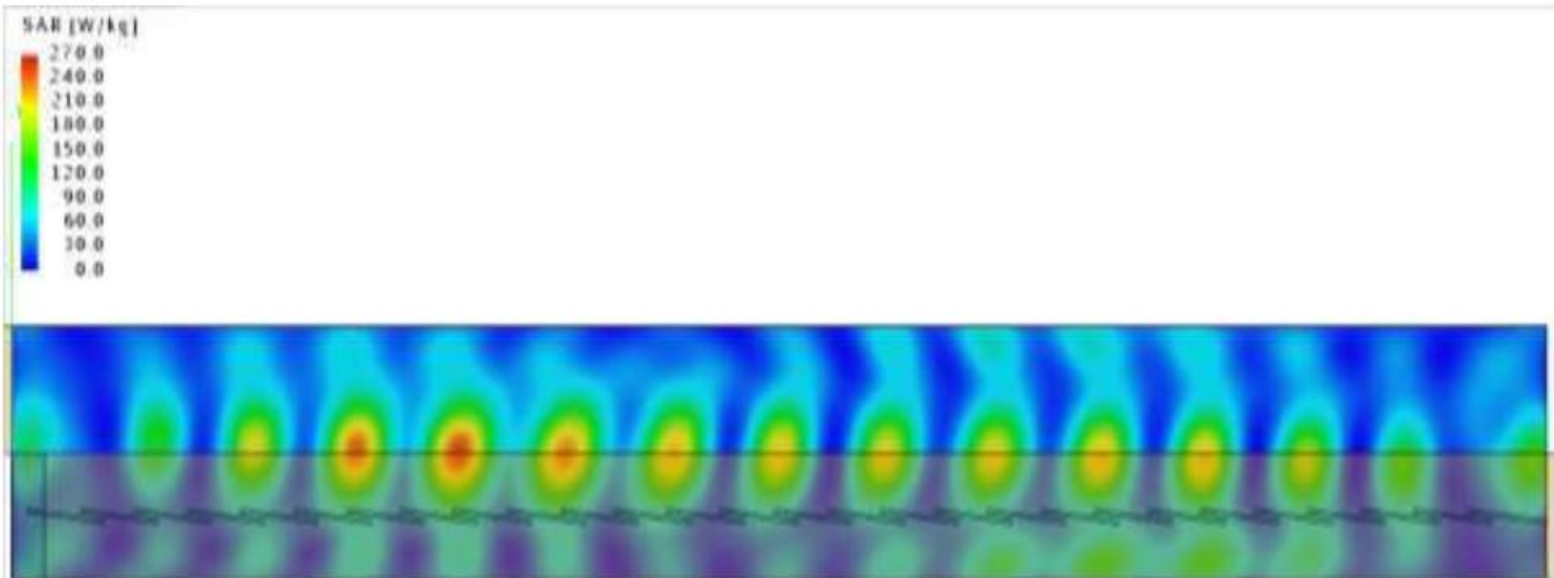

Figure 6. Distribution of specific absorbed power in the middle of the seed layer in the horizontal plane

The further away the waveguide is from the surface of the cuvette, the more evenly the electric field is distributed while simultaneously reducing the level of this field. It should be noted that in a real situation, the wave character of the field is smoothed due to heat transfer. It cannot be considered in the process of electromagnetic modeling. In addition, the entire spectrum of possible changes in the dielectric parameters of seed should be considered to analyze the wave propagation at high seed humidity.

\section{CONCLUSION}

The developed system of seed treatment increases crop yields stimulating the germination of agricultural crop seeds before sowing and disinfects seeds before storage using an electrophysical combined low-energy effect of infrared heating, microwave radiation and corona discharge.

\section{ACKNOWLEDGMENT}

The research was carried out under the project "Creation of high-tech production of hardware and software systems for processing agricultural raw materials based on microwave radiation" (Agreement with the Ministry of Education and Science of the Russian Federation № 075-11-2019-083 of 20.12.2019, SFedU Agreement № 18 of 20.09.2019, number of work in SFedU № XD/19-25-RT).

\section{REFERENCES}

[1] G. Brodie, M. V. Jacob, and P. Farrell. "Microwave and Radio-Frequency Technologies in Agriculture. An Introduction for Agriculturalists and Engineers", 2015.

[2] A. Dalmoroa, A. A. Barba, S. Caputob, F. Marrac, and G. Lambertic, "Microwave Technology Applied in PostHarvest Treatments of Cereals and Legumes", Chemical engineering transactions, vol. 44, 2015.

[3] V. I. Syrovatka, "SVCH-Obrabotka Kombikormov", Journal of VNIIMZH, vol.1, no.9, 29-37, 2013.

[4] F. Marra, "Microwave and Radio - Frequency Heating Processes for Food", in: Handbook of Food Process Design, pp. 1031-1056, 2012.

[5] D. N. Yadav, T. Anand, M. Sharma, and R. Gupta, "Microwave technology for disinfestation of cereals and pulses: An overview", Journal of Food Science and Technology, vol. 51, no. 12, 3568-3576, 2012. 
International Journal of Engineering Research and Technology. ISSN 0974-3154, Volume 13, Number 11 (2020), pp. 3964-3969

(C) International Research Publication House. https://dx.doi.org/10.37624/IJERT/13.11.2020.3964-3969

[6] A. A. Korolev, S. B. Tyurina, and M. V. Trishkaneva, "Analiz primeneniya mikrovolnovogo izlucheniya $\mathrm{v}$ tekhnologiyah sterilizacii rastitel'nogo syr'ya”, Nauchnyj zhurnal NIU ITMO. Seriya «Processy $i$ apparaty pishchevyh proizvodstv», vol. 3, 81-91, 2019.

[7] P. Puligundla, "Potentials of Microwave Heating Technology for Select Food Processing Applications - a Brief Overview and Update", Journal of Food Processing \& Technology, vol. 4, no. 11, 2-9, 2013.
[8] D. M. Pozar. "Microwave engineering", John Wiley \& Sons. 2011.

[9] G. V. Koz'min, S. A. Geras'kin, and N. I. Sanzharova. "Radiacionnye tekhnologii $v$ sel'skom hozyajstve $i$ pishchevoj promyshlennosti", Obninsk: VNII radiologii i agroekologii, 2015.

[10] I. A. Rogov, "Elektrofizicheskie metody obrabotki pishchevyh produktov", Moscow: Agropromizdat, 1989. 